\title{
Establishment of a continuous embryonic cell line from Japanese flounder Paralichthys olivaceus for virus isolation
}

\author{
Song-Lin Chen ${ }^{1, *}$, Guo-Cheng Ren ${ }^{1,2}$, Zhen-Xia Sha ${ }^{1}$, Cheng-Yin Shi ${ }^{1}$ \\ ${ }^{1}$ Yellow Sea Fisheries Research Institute, Chinese Academy of Fisheries Sciences, Qingdao 266071, PR China \\ ${ }^{2}$ College of Marine Life Science, China Ocean University, Qingdao 266003, PR China
}

\begin{abstract}
A continuous cell line, the flounder embryonic cell line (FEC), was established from gastrula-stage embryos of a marine cultured fish, the Japanese flounder Paralichthys olivaceus and cultured for more than $200 \mathrm{~d}$ with more than 60 passages. FEC cells were cultured in Dulbecco's Modified Eagle's Medium (DMEM) supplemented with antibiotics, fetal bovine serum (FBS), sea perch serum (SPS), and basic fibroblast growth factor (bFGF). The cells were small and round, and grew actively and stably in culture. The effect of temperature, FBS concentration and bFGF on FEC cell growth was examined. Cells grew well between 24 and $30^{\circ} \mathrm{C}$, but had a reduced growth rate below $18^{\circ} \mathrm{C}$. The growth rate of FEC cells in medium containing $15 \%$ FBS was higher than that in medium containing $7.5 \%$ FBS. Addition of bFGF to the medium also significantly increased the growth rate. Chromosome analysis revealed that FEC cells have a normal diploid karyotype with $2 n=48$. High survival rate was obtained after cryopreservation of cell cultures. The susceptibility of the cell line to piscine viruses was examined. Two viruses tested were shown to induce CPE (cytopathic effect) on FEC cells. FEC cell culture infected with fish iridovirus was further elucidated by electron microscopy. Many virus particles were found in the cytoplasm of the virus-infected FEC cells. These results indicated that the FEC cell line could be potentially used to isolate and study fish viruses.
\end{abstract}

KEY WORDS: Embryonic cell line $\cdot$ Flounder $\cdot$ Paralichthys olivaceus $\cdot$ Virus $\cdot$ Susceptibility

\section{INTRODUCTION}

Cell lines are powerful tools for studying epidemiology, molecular carcinogenesis, toxicology and functional genomics in fish (Hightower \& Renfro 1988, Bahich \& Borenfreund 1991, Bols \& Lee 1991, Wise et al. 2002). Cell lines are also essential for isolating and identifying many fish viruses. A large number of cell lines have been developed from freshwater teleosts (Fryer \& Lannan 1994), but relatively few cell lines have been developed in marine fish (Bejar et al. 1997, Chi et al. 1999, Chang et al. 2001, Chen et al. 2003a,b).
The Japanese flounder Paralichthys olivaceus is a widely cultivated marine fish species in China. However, intensive aquaculture has resulted in outbreaks of viral diseases with high mortalities. Lymphocystis disease (LCD) is one of the most devastating, causing mass mortality of juvenile Japanese flounder in China, and lymphocystis virus (LCV) has been identified as a pathogen of LCD in the flounder (Sun et al. 2000, Xu et al. 2000). Reddish body syndrome (RBS) is one of the viral diseases causing mass mortality of turbot Scophthalmus maximus. An iridovirus has been isolated from RBS-infected turbot and designated as TRBV (turbot reddish body virus; Shi et al. 2004). Due to a lack of 
suitable cell lines, little is known about the epidemiology of viral infections and characterization of the virus in lefteye flounders such as Japanese flounder and turbot. Although a gill cell line has been established in Japanese flounder, no susceptibility of this cell line to virus was observed (Tong et al. 1997). Thus, a cell line susceptible to virus is urgently needed in flounder, in order to isolate and identify the viruses causing viral diseases in this species.

The present study describes the development and characterization of an embryonic cell line from Japanese flounder and the sensitivity of this cell line to 2 fish viruses, LCV and TRBV.

\section{MATERIALS AND METHODS}

Primary cell culture and subculture. Gastrula-stage flounder embryos were harvested approximately $12 \mathrm{~h}$ after fertilization and prepared for cell culture. For each culture, a group of about 50 to 70 embryos were disinfected with $70 \%$ ethanol, washed with phosphate-buffered saline (PBS) and the chorions were torn with fine forceps. The cell mass was then released and the chorion membranes removed. Single cells were obtained by gentle pipetting. After several washes, the cells were transferred into gelatin-coated 24-well tissue plates. The complete growth medium (FECM1) was Dulbecco's Modified Eagle's Medium (DMEM) supplemented with 20 mM HEPES, pH 7.5, antibiotics (penicillin, $100 \mathrm{U} \mathrm{ml}^{-1}$; streptomycin, $100 \mathrm{\mu g} \mathrm{ml}^{-1}$; Gibco BRL), fetal bovine serum (FBS, 15\%), sea perch serum (SPS, $0.5 \%$ ) and basic fibroblast growth factor (bFGF, $2 \mathrm{ng} \mathrm{ml}^{-1}$; Gibco BRL). Cells were cultured at $24^{\circ} \mathrm{C}$ in an ambient air incubator. The growth medium was changed every 2 to $3 \mathrm{~d}$.

When reaching $95 \%$ confluence, the cells were subcultured at a ratio of 1:2 according to the standard trypsinization method. Briefly, cells were washed once with PBS and dissociated in trypsin/EDTA solution for 2 to $3 \mathrm{~min}$ at room temperature. The trypsin/EDTA solution was removed and complete medium was added. Cryopreservation of flounder embryonic cell line (FEC) cells was performed as previously described (Chen et al. 2003a). Cell cultures were suspended in complete medium with $10 \%$ dimethyl sulfoxide (DMSO) and $20 \%$ FBS, placed in cryovials and stored in liquid nitrogen.

Effect of temperature on cell growth. The effect of temperature on FEC proliferation was examined. A total of $2 \times 10^{5}$ cells were inoculated in 1 well of a 12 well plate, and incubated at $12,18,24$ or $30^{\circ} \mathrm{C}$ to test for growth. After $3 \mathrm{~d}$, cell density was measured microscopically by using a hemocytometer. The experiments were repeated 4 times.
Effect of FBS and bFGF on cell growth. Effect of FBS concentration and bFGF on the proliferation of FEC cells was examined. A total of $2 \times 10^{5}$ cells were inoculated in 1 well of a 12 -well plate and incubated at $24^{\circ} \mathrm{C}$. After 16 to $24 \mathrm{~h}$, the old medium was removed and various media containing different concentrations of FBS or bFGF were added. After $3 \mathrm{~d}$, cell density was measured microscopically by using a hemocytometer. The experiments were repeated 4 times.

Chromosome analysis. FEC cells at Passage 42 were used for chromosome analysis. The cells were inoculated in a $25 \mathrm{~cm}^{2}$ culture flask and incubated for 24 to $36 \mathrm{~h}$. Colchicine was added to the cells to reach a final concentration of $0.5 \mu \mathrm{g} \mathrm{ml}^{-1}$. After about $4 \mathrm{~h}$, the cells were harvested, treated with $5 \mathrm{ml}$ of a hypotonic solution of $0.075 \mathrm{M} \mathrm{KCl}$ for $25 \mathrm{~min}$, then pre-fixed for $2 \mathrm{~min}$ by adding $1 \mathrm{ml}$ of Carnoy's fixative. After centrifugation $(330 \times g$ for $5 \mathrm{~min})$, the cell pellet was fixed twice with cold Carnoy's fixative, for 15 min each time, and air dried. Chromosomes were stained with $5 \%$ Giemsa for $25 \mathrm{~min}$. Chromosome karyotype was analyzed according Levan (1964).

Susceptibility to virus and cytopathic effect. The 2 piscine viruses used for the susceptibility test, LCV and TRBV, were isolated from diseased Japanese flounder and turbot, respectively. The preparation of the 2 viruses was performed as described in Shi et al. (2004). For infection, FEC cells were inoculated in a well of a 24 -well plate or flask of $25 \mathrm{~cm}^{2}$ to give a confluence of 60 to $70 \%$, and incubated for 12 to $24 \mathrm{~h}$ at $24^{\circ} \mathrm{C}$. After removal of the medium, 0.1 or $1 \mathrm{ml}$ of virus suspension at a dilution of $10^{-1}$ to $10^{-3}$ was inoculated into the cell culture in a 24-well plate or flask, and allowed to absorb for $1 \mathrm{~h}$. Then 0.5 or $5 \mathrm{ml}$ of maintenance medium containing $5 \%$ FBS was added. The cells were incubated at $24^{\circ} \mathrm{C}$ and examined daily for the appearance of cytopathic effect (CPE).

Electron microscopy. Electron microscopy preparation was performed as described in Chang et al. (2001) with some modifications. Briefly, once CPE was observed, the inoculated monolayer cells cultured in $25 \mathrm{~cm}^{2}$ flasks were scraped and centrifuged at $167 \times g$ for $10 \mathrm{~min}$, followed by the fixation in $2.5 \%$ glutaraldehyde in cacodylate buffer $(0.1 \mathrm{M}, \mathrm{pH} 7.4)$ for $24 \mathrm{~h}$ at $4^{\circ} \mathrm{C}$. The fixed cells were rinsed and then postfixed in $1 \% \mathrm{OsO}_{4}$ in cacodylate buffer $(0.1 \mathrm{M}, \mathrm{pH} 7.4)$ for $1.5 \mathrm{~h}$. Pelleted cells were embedded in Epon 812 resin, sectioned and stained with $2 \%$ uranyl acetate and lead citrate, then examined and photographed under a JEM-1200EX TEM (JEOL).

Statistical analysis. Data were expressed as mean N $\pm \mathrm{SD}$. The cell amount was analyzed with independent sample tests. A value of $p<0.05$ was considered as statistically significant. The statistical analysis was computed using SPSS software (version 11.5). 


\section{RESULTS}

\section{Establishment of embryonic cell line}

To develop an embryonic cell line in marine cultured fish, gastrula-stage embryos of Paralichthys olivaceus were used. The single cells from 50 to 70 embryos were isolated and inoculated in 1 well of a 24 -well plate. These cells (approx. 10 to $25 \mu \mathrm{m}$ in diameter) first evenly attached to the surface of the well, then moved to form numerous dense, homogeneous aggregates within the first 12 to $24 \mathrm{~h}$ after inoculation. After 2 or $3 \mathrm{~d}$, the cells grew to confluence in the well, and could be subcultured. Cell divisions occurred very rapidly and subculture could be done once every 3 or $4 \mathrm{~d}$. The FEC cultures at Passages 16 and 46 are shown in Fig. 1. In early subcultures of up to 20 passages, both epithelial-like and fibroblast-like cells were present (Fig. 1B). After 20 subcultures, epithelial-like cells became the predominant cell type (Fig. 1C). At this point, the FEC cells had been cultivated for more than $200 \mathrm{~d}$ with more than 60 passages. The time of reaching confluence, the maintenance medium used and the ratio of subcultures after the 60 passages were the same as before the 60 passages. The cryopreservation tests demonstrated that FEC cells could undergo cryopreservation in liquid nitrogen $\left(-196^{\circ} \mathrm{C}\right)$ with a survival rate of about $60 \%$.

\section{Effect of temperature on growth of FEC cells}

FEC cells exhibited different growth at different temperature (Fig. 2). The growth of FEC cells increased as culture temperature increased, when the temperature was between 12 and $24^{\circ} \mathrm{C}$. Although cells grew well at 24 and $30^{\circ} \mathrm{C}$, the growth rate of cells cultured at $30^{\circ} \mathrm{C}$ began to decrease. The growth rate declined markedly at 18 and $12^{\circ} \mathrm{C}(\mathrm{p}<$ 0.05).

\section{Effect of FBS concentration and bFGF on FEC cell growth}

The effect of FBS concentration and bFGF on proliferation of FEC cells is shown in Fig. 3. The growth rate of FEC cells in medium containing $15 \%$ FBS (FECM1) was higher than that of FEC cells in medium containing $7.5 \%$ FBS (FECM2) $(p<0.05)$. The absence of bFGF significantly decreased the proliferation of FEC cells (FECM3) $(p<0.05)$. The absence of $0.5 \%$ SPS did not influence FEC cell growth (FECM4).

\section{Karyotypic analysis}

The results of chromosome counts of 100 metaphase plates from FEC cells at Passage 45 revealed that the chromosome numbers varied from 24 to 74 ; nevertheless, the modal number of chromosomes was 48 , and $64 \%$ of the cells contained 48 chromosomes (Fig. 4A). The distribution was asymmetrical, most $2 n$ values appearing clustered below the modal value. Both ane-
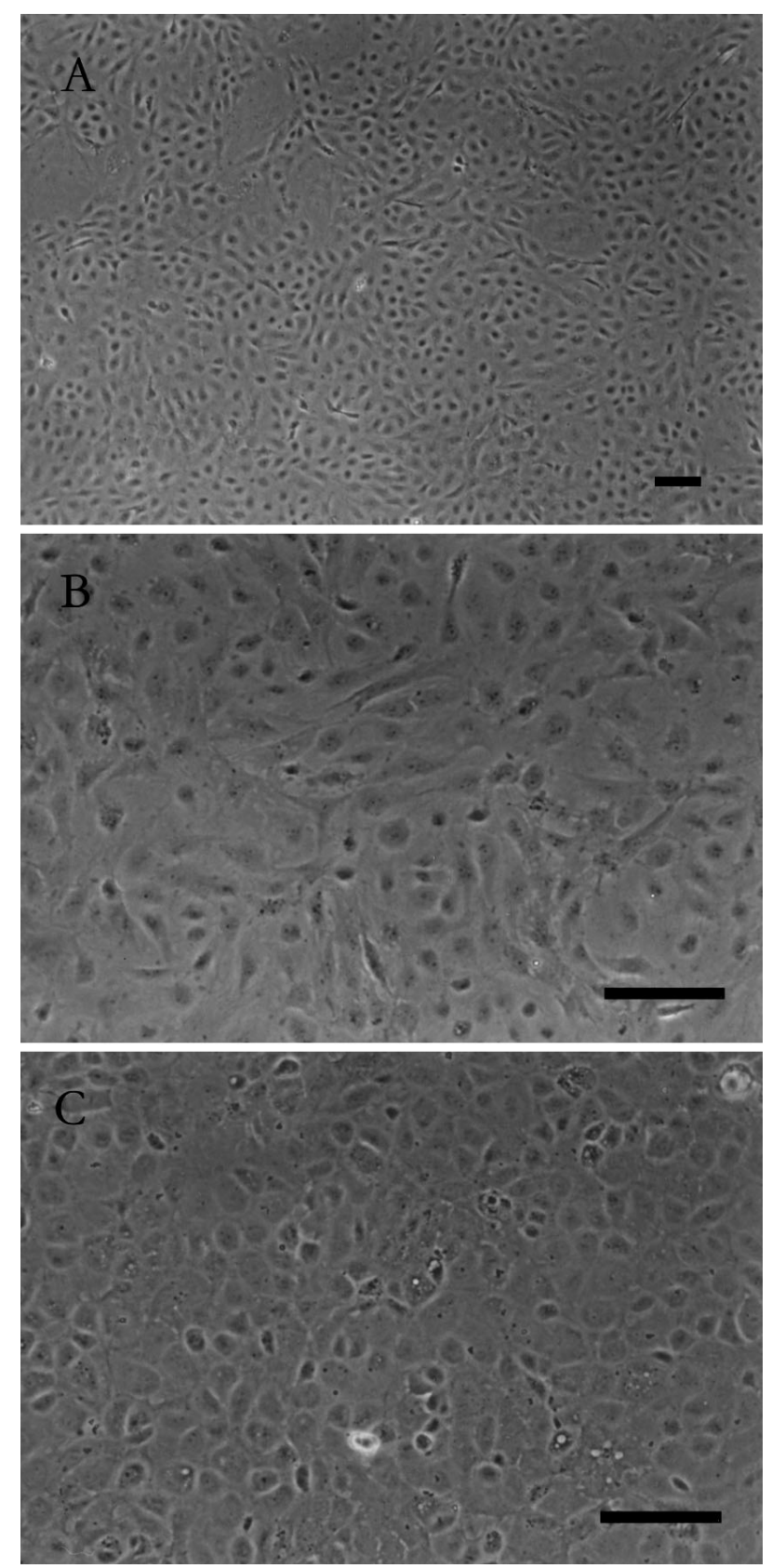

Fig. 1. Morphology and culture of flounder embryonic cell line cells (FEC) at (A,B) Passages 16 and (C) 46. Scale bars = $100 \mu \mathrm{m}$ 


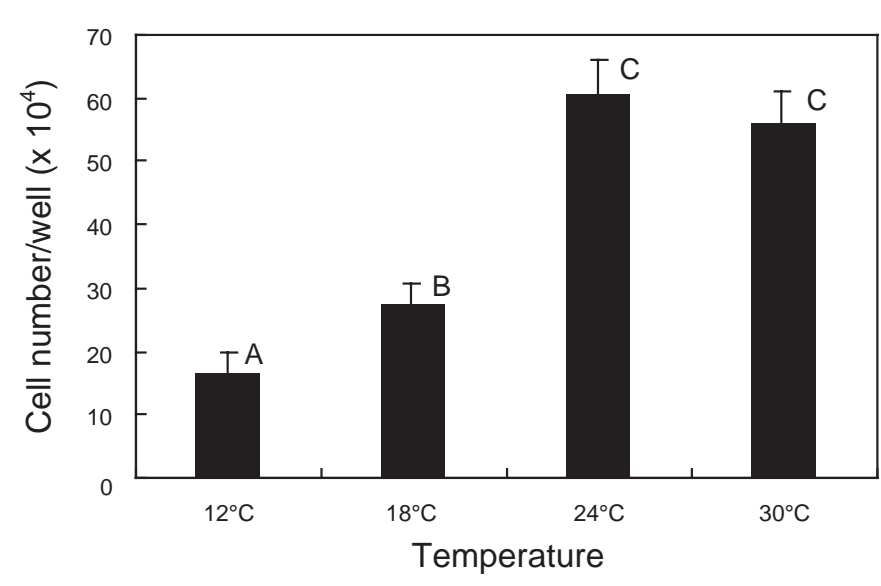

Fig. 2. Effect of temperature on FEC cell growth and proliferation. Letters above the columns represent significantly different values $(p<0.05)$, expressed as mean \pm SEM $(n=4)$

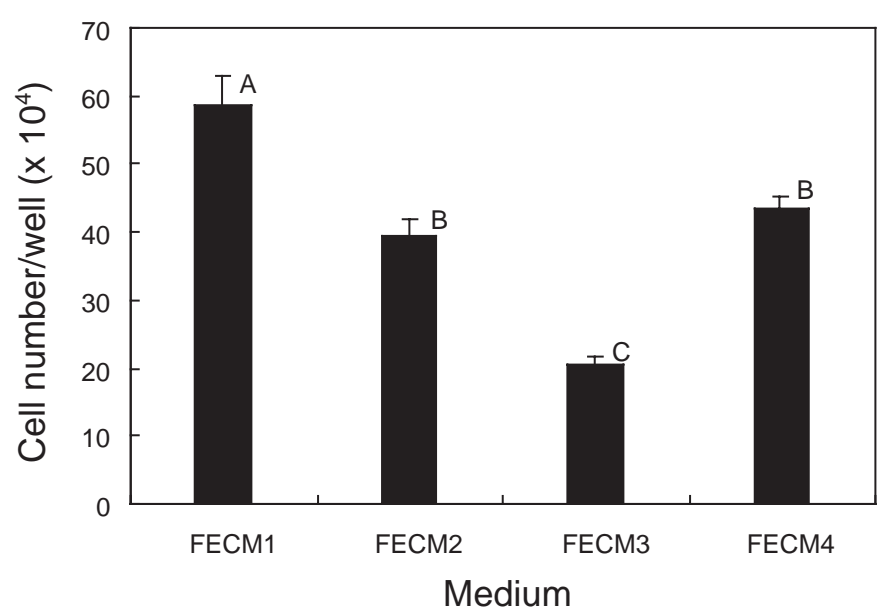

Fig. 3. Effect of fetal bovine serum (FBS) and basic fibroblast growth factor (bFGF) FEC cell growth and proliferation. Letters above the columns represent significantly different values $(p<0.05)$, expressed as mean \pm SEM $(n=4)$. FECM1: $15 \%$ FBS, $2 \mathrm{ng} \mathrm{ml}^{-1}$ bFGF and $0.5 \%$ sea perch serum (SPS); FECM2: $7.5 \%$ FBS, $2 \mathrm{ng} \mathrm{ml}^{-1} \mathrm{bFGF}, 0.5 \%$ SPS; FECM3: $15 \%$ FBS, $0.5 \%$ SPS; FECM $4: 7.5 \%$ FBS, $2 \mathrm{ng} \mathrm{ml}^{-1} \mathrm{bFGF}$

uploidy and heteroploidy appeared in the FEC in small proportions. The metaphase (Fig. 4B) with a normal diploid number $(2 n)$ displayed the normal karyotype morphology (Fig. 4C) consisting of 24 pairs of telocentrics $(2 n=48 \mathrm{t})$.

\section{Virus susceptibility and electron microscopy}

The suitability of the FEC for virus isolation was evaluated by its susceptibility to 2 fish viruses (LCV and TRBV). Significant CPE was observed in FEC cells $4 \mathrm{~d}$ post-infection with TRBV (Fig. 5A) and $5 \mathrm{~d}$ with LCV

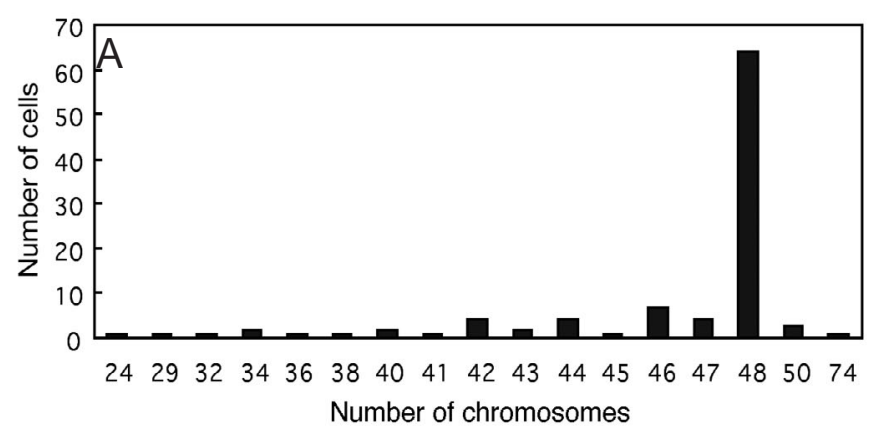

B

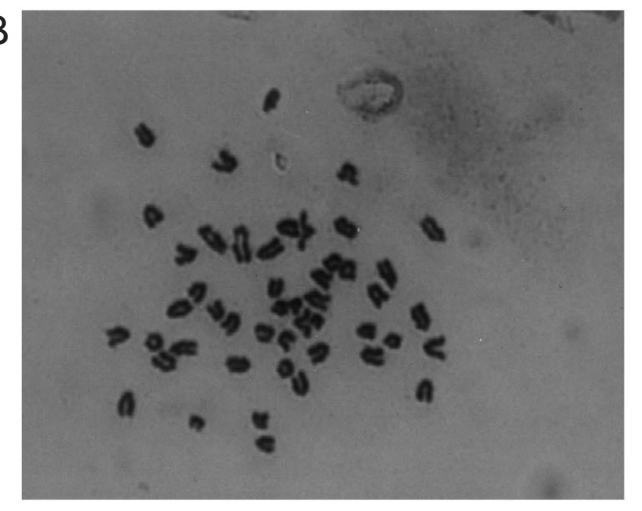

C

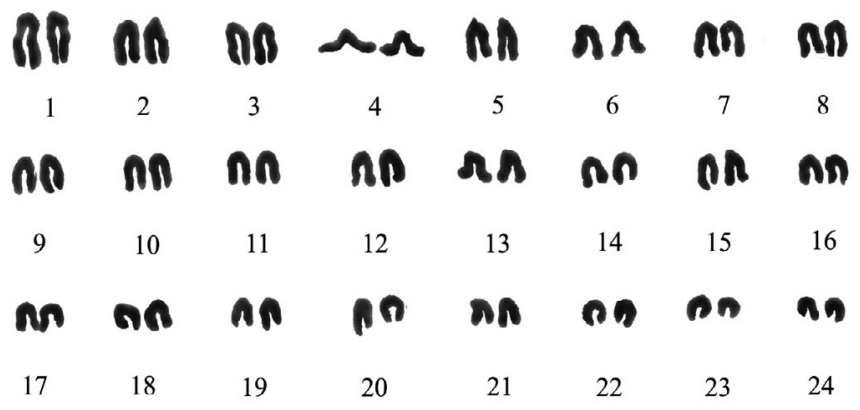

Fig. 4. (A) Chromosome number distribution, (B) metaphase and (C) diploid karyotype of FEC cells at Passage 45. In total, 100 metaphases were counted

(Fig. 5B). About 20 to $30 \%$ of the infected cells became round in shape and began to shrink $48 \mathrm{~h}$ post-infection. Of the infected cells, 50 to $60 \%$ shrank $72 \mathrm{~h}$ post-infection. More than $80 \%$ of the infected cells shrank (Fig. 5A) or degenerated and detached (Fig. 5B) 96 to $120 \mathrm{~h}$ post-infection. No CPE was observed in uninfected FEC cells (Fig. 5C). Electron microscopy of the TRBV-infected FEC cells revealed that many viral particles were present in the cytoplasm (Fig. 6A,C). The viral particles were icosahedral in shape and were $120 \mathrm{~nm}$ in outer diameter, with an inner electron-dense central core $50 \mathrm{~nm}$ in diameter (Fig. 6B,C). 


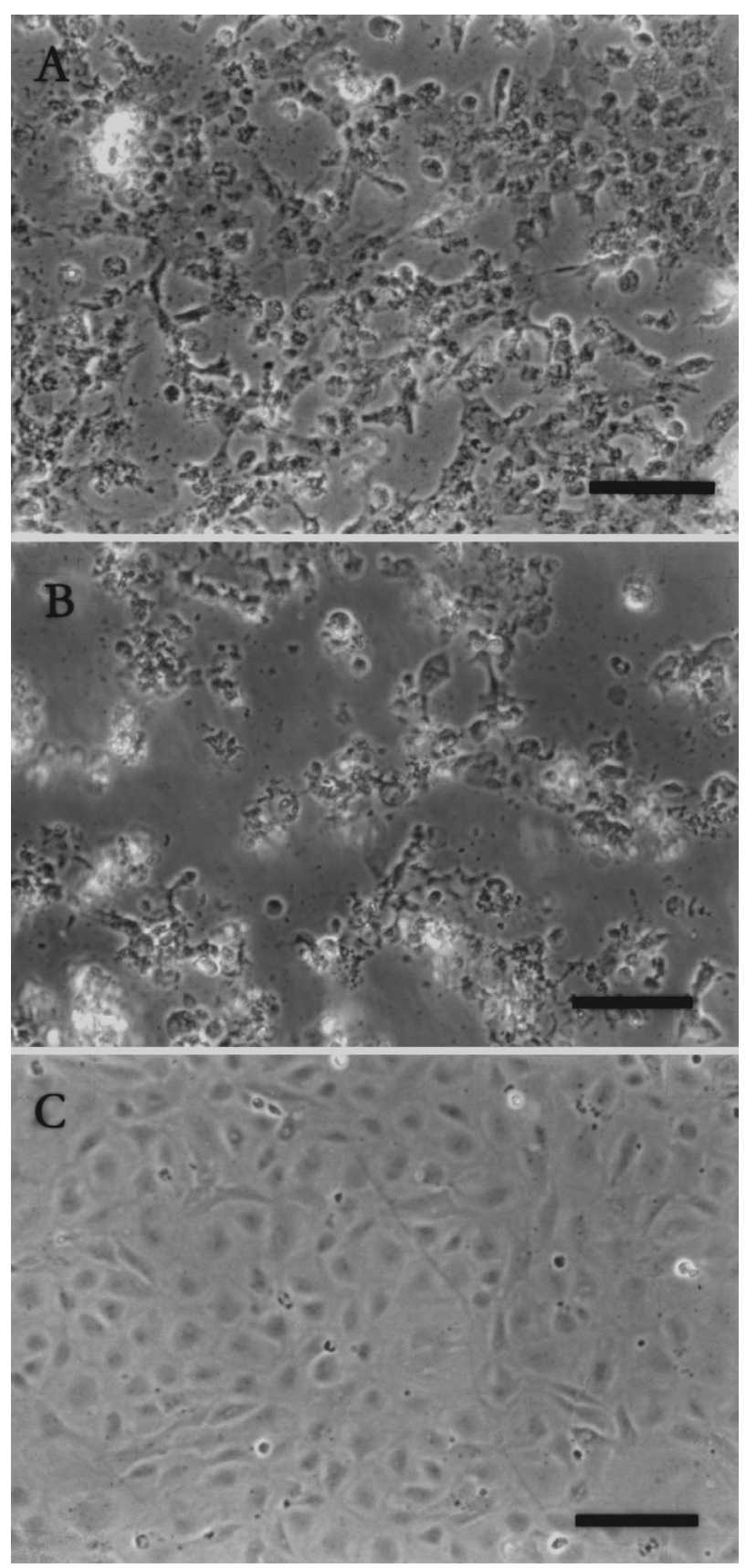

Fig. 5. CPE (cytopathic effect) of FEC cells at Passage 24 (A) $4 \mathrm{~d}$ post-infection by TRBV, and (B) $5 \mathrm{~d}$ post-infection by LCV. (C) Uninfected FEC cells. Dilution of TRBV and LCV was $10^{-2}$. Scale bars $=100 \mu \mathrm{m}$

\section{DISCUSSION}

Cell lines have been recognized as powerful experimental tools in vertebrate immunology and biology. The importance of animal cell lines for the study of viruses, especially for cultured marine fish, is gaining increasing attention (Wise et al. 2002). Thus far, few cell lines have
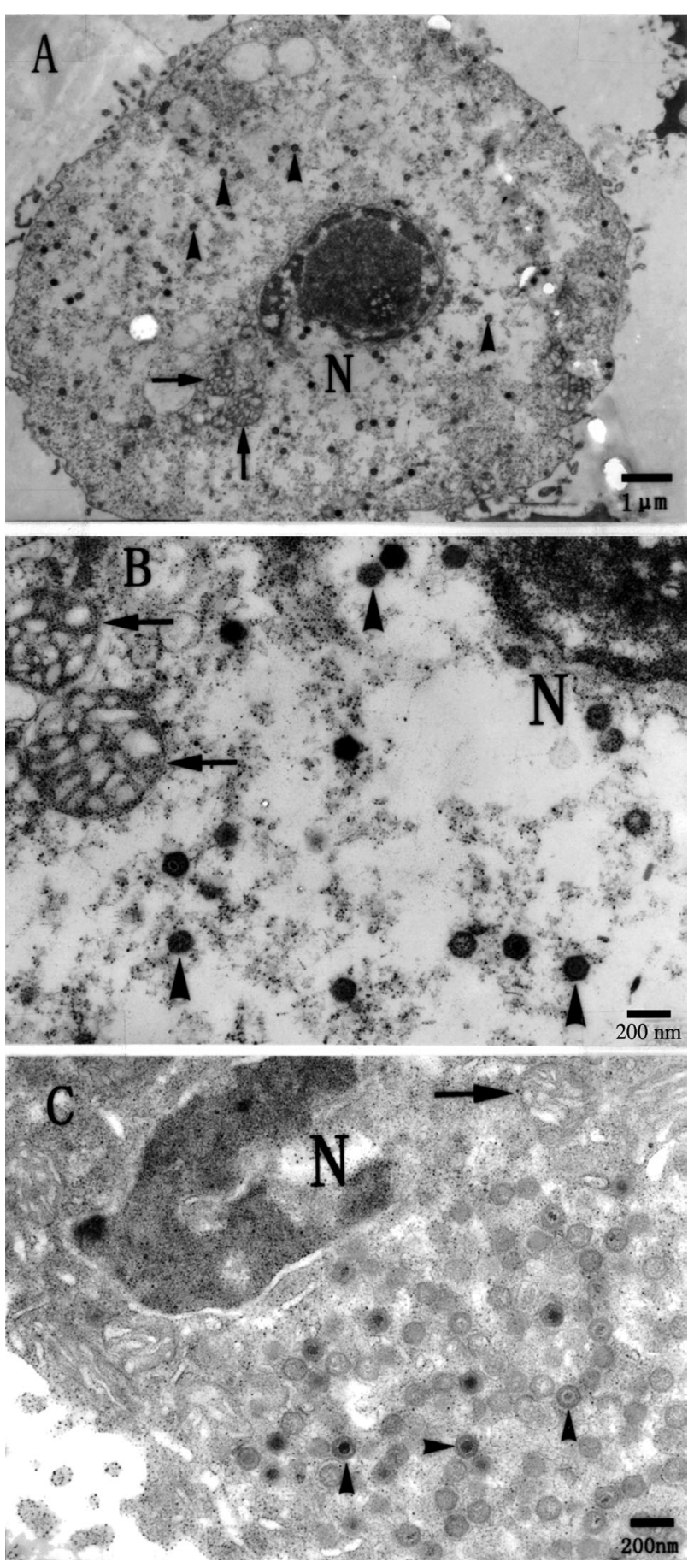

Fig. 6. Electron micrograph of TRBV-infected FEC cells. (A) Cell containing many virus particles; $(\mathrm{B}, \mathrm{C})$ morphology and size of TRBV viral particles. N: nucleus. Arrow: mitochondria; arrowhead: viral particles. Scale bars $=(A) 1 \mu \mathrm{m}$, (B,C) $200 \mathrm{~nm}$

been developed in cultured marine fish, especially in lefteye flounders such as Japanese flounder (Tong et al. 1997). The present study reports the establishment of an embryonic cell line, FEC, derived from gastrula-stage 
embryos of the flounder. The cell line maintained stable growth and normal diploid karyotype over $200 \mathrm{~d}$ of culture with more than 60 passages.

Basic fibroblast growth factor (bFGF) is a potent mitogenic agent for human melanocytes (Halaban et al. 1998). In zebrafish, bFGF proved to be mitogenic and suppressed melanogenesis (Bradford et al. 1994). In Japanese flounder, the present study demonstrated that bFGF stimulates proliferation of FEC cells and can be used as a potent mitogenic factor in FEC and other cell cultures.

The euploid karyotype is an important parameter for characterizing a cell line. Karyotype analysis revealed that over $64 \%$ of the cells possessed a diploid chromosome number of $2 n=48$, which was identical to the modal chromosome number of Japanese flounder (Liu et al. 1999). This diploid rate is similar to or higher than other reports in other fish cell lines (Sun et al. 1995, Hong et al. 1996, Chen et al. 2003a).

Susceptibility of cell lines to viral infection is the basis for isolating and characterizing fish viruses. Although a cell line was developed from the gill of flounder Paralichthys olivaceus, no susceptibility of this cell line to fish virus was observed (Tong et al. 1997). The lack of suitable cell lines susceptible to fish virus has limited the isolation and characterization of infectious virus from the flounder. The present study demonstrated that CPE occurred in FEC 2 to $3 \mathrm{~d}$ after infection with LCV or TRBV, indicating that viral diagnosis might be made with the FEC within $3 \mathrm{~d}$. The presence of many viral particles in the cytoplasm of virus-infected FEC cells indicates that TRBV can be propagated in FEC cells, and confirms the potential of the FEC cell line as a powerful tool for isolating and identifying infectious viruses from the flounder.

In summary, an embryonic cell line, FEC, was established from gastrula-stage embryos of Japanese flounder, and exhibited susceptibility to 2 piscine viruses, LCV and TRBV. The availability of an FEC susceptible to virus provides an important tool for the study of infectious viruses in lefteye flounders such as Japanese flounder, and lays the foundation for developing cell models for screening immune-related functional genes in this species.

Acknowledgements. This work was supported by grants from the State 863 High-Technology R\&D Project of China (2002AA626010) and from the National Nature Science Foundation of China (40376047).

\section{LITERATURE CITED}

Bahich H, Borenfreund E (1991) Cytotoxicity and genotoxicity assays with cultured fish cells: a review. Toxicol Vitro 5: 91-100

Editorial responsibility: Jo-Ann Leong, Kaneohe, Hawaii, USA
Bejar J, Borrego JJ, Alvarez MC (1997) A continuous cell line from the cultured marine fish gilt-head seabream (Sparus aurata). Aquaculture 150:143-153

Bols NC, Lee LEJ (1991) Technology and uses of cell culture from tissues and organs of bony fish. Cytotechnol 6: 163-187

Bradford CS, Sun L, Barnes DW (1994) Basic fibroblast growth factor stimulates proliferation and suppresses melanogenesis in cell cultures derived from early zebrafish embryos. Mol Mar Biol Biotechnol 3:78-86

Chang SF, Ngoh GH, Kueh LFS, Qin QW, Chen CL, Lam TJ, Sin YM (2001) Development of a tropical marine fish cell line from Asian seabass (Lates calcarifer) for virus isolation. Aquaculture 192:133-145

Chen SL, Sha ZX, Ye HQ (2003a) Establishment of a pluripotent embryonic cell line from sea perch blastula embryo. Aquaculture 218:141-151

Chen SL, Ye HQ, Sha ZX, Hong Y (2003b) Derivation of a pluripotent embryonic cell line from red sea bream blastulas. J Fish Biol 63:795-805

Chi SC, Hu WW, Lo BJ (1999) Establishment and characterization of a continuous cell line (GF-1) derived from grouper, Epinephelus coioides: a cell line susceptible to grouper nervous necrosis virus (GNNV). J Fish Dis 22: 173-182

Fryer JL, Lannon CN (1994) Three decades of fish cell culture: a current listing of cell lines derived from fish. J Tissue Cult Methods 16:87-94

Halaban R, Langdon R, Birchall N, Cuono C, Baird A, Scott G, Moellman G, McGuire J (1988) Basic fibroblast growth factor from human keratinocytes is a natural mitogen for melanocytes. J Cell Biol 107:1611-1619

Hightower LH, Renfro JL (1988) Recent applications of fish cell culture to biomedical research. J Exp Zool 248: 290-302

Hong Y, Winkler C, Schartl M (1996) Pluripotency and differentiation of embryonic stem cell lines from the medakafish (Oryzias latipes). Mech Develop 60:33-44

Levan A (1964) Nomenclature for centromeric poisition on chromosomes. Hereditas 52:201-220

Liu J, You F, Wang XC, Xu YL, Zhang PJ (1999) Chromosome and karyotype evidence of artificial induced gynogenesis in the olive flounder Paralichthys olivaceus. Ocean Limnol Sinica 30:68-72

Shi CY, Wang YG, Yang SL, Huang J, Wang QY (2004) The first report of an iridovirus-like agent infection in farmed turbot Scophthalmus maximus in China. Aquaculture (in press)

Sun L, Bradford CS, Ghosh C, Collodi P, Barnes DW (1995) ES-like cell cultures derived from early zebrafish embryos. Mol Mar Biol Biotechnol 4:193-199

Sun XQ, Qu LY, Zhang JX (2000) Pathogenicity and immunogenicity of lymphocystis virus of Japanese flounder (Paralichthys olivaceus). High Tech Letters 9:19-21 (in Chinese)

Tong SL, Li H, Miao HZ (1997) The establishment and partial characterization of a continuous fish cell line FG-9307 from the gill of flounder Paralichthys olivaceus. Aquaculture 156:327-333

Wise JP Sr, Winn RN, Renfro JL (2002) Generating new marine cell lines and transgenic species. J Exp Zool 15: 292-295

Xu HT, Pu CA, Jiang ZL (2000) Pathogen of Lymphocystis disease in cultured Japanese flounder (Paralichthys olivaceus). J Virol 16:223-226 (in Chinese)

Submitted: January 5, 2004; Accepted: May 26, 2004

Proofs received from author(s): August 11, 2004 